\title{
Biomass Burning Effects on the Climate over Southern West Africa During the Summer Monsoon
}

\author{
Alima Dajuma, Siélé Silué, Kehinde O. Ogunjobi, Heike Vogel, \\ Evelyne Touré N'Datchoh, Véronique Yoboué, Arona Diedhiou, and \\ Bernhard Vogel
}

\section{Contents}

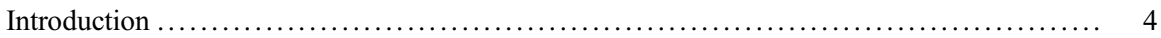

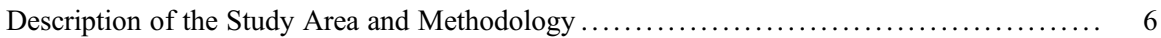

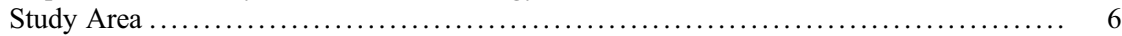

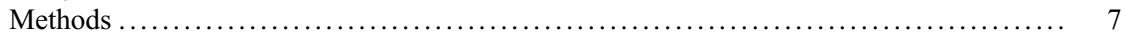

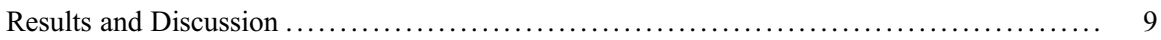

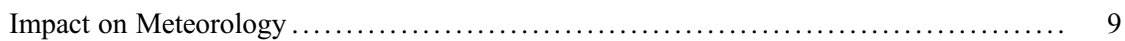

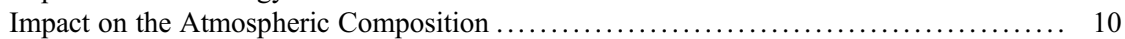

Adaptation and Mitigation Strategies ....................................... 14

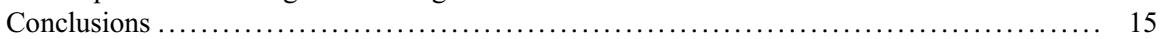

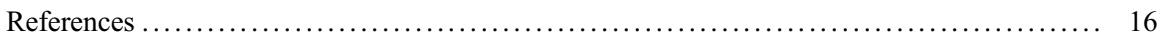

This chapter was previously published non-open access with exclusive rights reserved by the Publisher. It has been changed retrospectively to open access under a CC BY 4.0 license and the copyright holder is "The Author(s)". For further details, please see the license information at the end of the chapter.

\footnotetext{
A. Dajuma $(\bowtie)$

Department of Meteorology and Climate Sciences, West African Science Service Centre on Climate Change and Adapted Land Use (WASCAL), Federal University of Technology Akure (FUTA),

Ondo State, Nigeria

Laboratoire de Physique de l'Atmosphère et de Mécaniques des Fluides (LAPA-MF),

Université Félix Houphouët-Boigny, Abidjan, Côte d'Ivoire

e-mail: alima.dajuma@yahoo.com

S. Silué

Université Peleforo Gon Coulibaly, Korhogo, Côte d'Ivoire

e-mail: sielesil@yahoo.fr
} 


\section{Abstract}

Biomass Burning (BB) aerosol has attracted considerable attention due to its detrimental effects on climate through its radiative properties. In Africa, fire patterns are anticorrelated with the southward-northward movement of the intertropical convergence zone (ITCZ). Each year between June and September, BB occurs in the southern hemisphere of Africa, and aerosols are carried westward by the African Easterly Jet (AEJ) and advected at an altitude of between 2 and $4 \mathrm{~km}$. Observations made during a field campaign of Dynamics-Aerosol-ChemistryCloud Interactions in West Africa (DACCIWA) (Knippertz et al., Bull Am Meteorol Soc 96:1451-1460, 2015) during the West African Monsoon (WAM) of June-July 2016 have revealed large quantities of BB aerosols in the Planetary Boundary Layer (PBL) over southern West Africa (SWA).

This chapter examines the effects of the long-range transport of $\mathrm{BB}$ aerosols on the climate over SWA by means of a modeling study, and proposes several adaptation and mitigation strategies for policy makers regarding this phenomenon. A high-resolution regional climate model, known as the Consortium for Small-scale Modelling - Aerosols and Reactive Traces (COSMO-ART) gases, was used to conduct two set of experiments, with and without BB emissions, to quantify their impacts on the SWA atmosphere. Results revealed a reduction in surface shortwave (SW) radiation of up to about $6.5 \mathrm{~W} \mathrm{~m}^{-2}$ and an $11 \%$ increase of Cloud Droplets Number Concentration (CDNC) over the SWA domain. Also, an increase of $12.45 \%$ in Particulate Matter $\left(\mathrm{PM}_{25}\right)$ surface concentration was observed in Abidjan $\left(9.75 \mu \mathrm{g} \mathrm{m}^{-3}\right)$, Accra $\left(10.7 \mu \mathrm{g} \mathrm{m}^{-3}\right)$, Cotonou $\left(10.7 \mu \mathrm{g} \mathrm{m}^{-3}\right)$, and Lagos $\left(8 \mu \mathrm{g} \mathrm{m}^{-3}\right)$, while the carbon monoxide (CO) mixing ratio increased by $90 \mathrm{ppb}$ in Abidjan and Accra due to BB. Moreover, BB aerosols were found to contribute to a

K. O. Ogunjobi

Department of Meteorology and Climate Sciences, West African Science Service Centre on Climate Change and Adapted Land Use (WASCAL), Federal University of Technology Akure (FUTA), Ondo State, Nigeria

Federal University of Technology Akure (FUTA), Ondo State, Nigeria e-mail: kenog2010@gmail.com

H. Vogel · B. Vogel

Institute of Meteorology and Climate Research, Karlsruhe Institute of Technology (KIT), Karlsruhe, Germany

e-mail: heike.vogel@kit.edu; bernhard.vogel@kit.edu

E. T. N'Datchoh · V. Yoboué

Laboratoire de Physique de l'Atmosphère et de Mécaniques des Fluides (LAPA-MF),

Université Félix Houphouët-Boigny, Abidjan, Côte d'Ivoire

e-mail: ndatchoheve@yahoo.fr; yobouev@hotmail.com

\section{A. Diedhiou}

Laboratoire de Physique de l'Atmosphère et de Mécaniques des Fluides (LAPA-MF),

Université Félix Houphouët-Boigny, Abidjan, Côte d'Ivoire

Université Grenoble Alpes, IRD, Grenoble INP, IGE, Grenoble, France

e-mail: arona.diedhiou@gmail.com 
$70 \%$ increase of organic carbon (OC) below $1 \mathrm{~km}$ in the PBL, followed by black carbon (BC) with $24.5 \%$. This work highlights the contribution of the long-range transport of BB pollutants to pollution levels in SWA and their effects on the climate. It focuses on a case study of 3 days (5-7 July 2016). However, more research on a longer time period is necessary to inform decision making properly.

This study emphasizes the need to implement a long-term air quality monitoring system in SWA as a method of climate change mitigation and adaptation.

\section{Keywords}

Adaptation strategy $\cdot$ Biomass burning $\cdot$ lowland $\cdot$ Southern West Africa $\cdot$ Modeling

\section{List of Abbreviations}

$\begin{array}{ll}\text { ADF } & \text { Abidjan domestic fire } \\ \text { AEJ } & \text { African easterly jet } \\ \text { AGL } & \text { Altitude above ground level } \\ \text { AOD } & \text { Aerosol optical depth } \\ \text { BB } & \text { Biomass burning } \\ \text { BC } & \text { Black carbon } \\ \text { CDNC } & \text { Cloud droplets number concentration } \\ \text { CO } & \text { Carbon monoxide } \\ \text { COSMO-ART } & \text { Consortium for Small-scale Modelling - Aerosols and } \\ & \text { Reactive Traces gases } \\ \text { DACCIWA } & \text { Dynamics-Aerosol-Chemistry-Cloud Interactions in West } \\ & \text { Africa } \\ \text { DMS } & \text { Dimethyl sulfide } \\ \text { DWD } & \text { German weather service } \\ \text { EDGAR HTAP_v2 } & \text { Emission Database for Global Atmospheric Research } \\ & \text { Hemispheric Transport of Air Pollution version 2 } \\ \text { FRP } & \text { Fire radiative power } \\ \text { GFAS } & \text { Global Fire Assimilation System } \\ \text { ICON } & \text { Icosahedral nonhydrostatic } \\ \text { ITCZ } & \text { Intertropical convergence zone } \\ \text { ITD } & \text { Intertropical discontinuity } \\ \text { MODIS } & \text { Moderate Resolution Imaging Spectroradiometer } \\ \text { MOZART } & \text { Model for Ozone and Related Chemical Tracers } \\ \text { NOx } & \text { Nitrogen oxide } \\ \text { OC } & \text { Organic carbon } \\ \text { PBL } & \text { Planetary boundary layer } \\ \text { PM } & \text { Particulate matter } \\ \text { STRATOZ } & \text { Stratospheric ozone experiment } \\ \text { SW } & \text { Shortwave } \\ \text { SWA } & \text { Southern West Africa } \\ \text { TOA } & \text { Top of atmosphere } \\ & \\ & \end{array}$


TROPOZ

WAM

WHO

WRF-Chem
Tropospheric ozone experiment

West African monsoon

World Health Organisation

Weather Research and Forecasting model coupled with Chemistry

\section{Introduction}

Biomass Burning (BB) is one of the major sources of aerosols in Africa after Saharan dust. In the form of submicron accumulation mode $\mathrm{BB}$ pollutants are mainly composed of organic carbon (OC) and black carbon (BC) aerosols and carbon monoxide $(\mathrm{CO})$, hydrocarbon, and nitrogen oxide $\left(\mathrm{NO}_{\mathrm{x}}\right)$, as gaseous pollutants. During the previous decades, an increasing number of studies have investigated the impacts of BB aerosols on radiation, weather, and climate. In general, the African fire pattern is strongly associated with the southward movement of the intertropical convergence zone (ITCZ) (N'Datchoh et al. 2015; Swap et al. 2002). BB occurs as a result of anthropogenic activities, such as land management, livestock grazing, and crop production (Bowman et al. 2011; Stowe et al. 2002; Mbow et al. 2000). BB is an important source of aerosols and trace gases in the atmosphere, with an estimated burned biomass of 3260-10,450 $\mathrm{Tg} \mathrm{a}^{-1}$ for tropical areas (Barbosa et al. 1999). Hao and Liu (1994) estimated that there was an amount of $2500 \mathrm{Tg} \mathrm{a}^{-1}(46 \%$ of the tropics in total) over the tropical regions of Africa, to which the savanna contributes up to $1600 \mathrm{Tg} \mathrm{a}^{-1}$ (30\% of the total amount over the tropics).

$\mathrm{BB}$ affects the radiative energy budget of the Earth by absorbing and scattering solar radiation and modifies the properties of clouds as they serve as cloud condensation nuclei (CCN) or ice nuclei (IN). The global mean direct radiative effect of BC and $\mathrm{OC}$ from $\mathrm{BB}$ was quantified as being $0.155 \mathrm{~W} \mathrm{~m}^{-2}$ for their overall effect, with $0.25 \mathrm{~W} \mathrm{~m}^{-2}$ for BC (absorption) and -0.005 to $+0.4 \mathrm{~W} \mathrm{~m}^{-2}$ for OC (Jiang et al. 2016). BC traps a significant part of solar radiation in the atmosphere, thus reducing the surface incoming radiation as well as low surface sensible and latent heat fluxes (Huang et al. 2016). A modeling study by Walter et al. (2016) investigated the impact of the Canadian forest fires that occurred in July 2010 on SW radiation and temperature using the regional climate model, Consortium for Small-scale Modelling - Aerosols and Reactive Traces gases (COSMO-ART). Downwelling surface SW radiation was found to be reduced by up to $50 \%$ below the biomass plume under cloudless conditions due to absorption in dense smoke layers, furthermore leading to a decrease of up to $6 \mathrm{~K}$ of 2-m temperature. Surface cooling, as well as a warming in elevated layers, led to an increase in atmospheric stability, which induce a decrease of precipitation.

Thornhill et al. (2018) analyzed 30-year simulation to assess the impact of BB on the regional climate of South America. The simulations found a decrease in the downwelling clear-sky and all-sky SW radiation at the surface by $13.77 \mathrm{~W} \mathrm{~m}^{-2}$ and $7.37 \mathrm{~W} \mathrm{~m}^{-2}$, respectively. Mean surface temperature was reduced by $0.14 \pm 0.24{ }^{\circ} \mathrm{C}$ and a mean precipitation decrease of $14.5 \%$ was found in the peak region of $\mathrm{BB}$. The authors found that, if BB increases during a particular dry season, the resulting 
decrease in precipitation may in fact exacerbate drought. Pani et al. (2016) estimated the direct aerosol radiative effects of BB aerosols over northern Indochina from observed ground measurements of the optical properties of such aerosols. They found that the overall mean aerosol radiative forcing was $-8 \mathrm{~W} \mathrm{~m}^{-2}$ and $-31.4 \mathrm{~W} \mathrm{~m}^{-2}$ at TOA and at the surface, respectively.

Similarly, Huang et al. (2013) investigated the impact of direct radiative forcing of BC on West African Monsoon (WAM) precipitation during the dry season, and concluded that there was a reduction in precipitation in the WAM region due to the radiative effect of $\mathrm{BC}$. They demonstrated that aerosols from the southern African hemisphere significantly reduced convective precipitation, particularly during the boreal cold season, when BB smoke was prevalent. They also highlighted that BB can affect local weather and climate over West Africa. These results suggest that reductions in cloud amount, cloud top height, and surface precipitation are due to a high $\mathrm{BC}$ aerosols load in the atmosphere.

During the airborne measurement campaigns of the Stratospheric Ozone Experiment (STRATOZ) of March 1985 and the Tropospheric Ozone Experiment (TROPOZ) of December 1987, Marenco et al. (1990) discovered that large CO concentrations are present over the mid-Atlantic Ocean as well over West Africa, which is evidence of the lofting of BB from Central and Southern Africa. The plumes arising from agricultural burning fumes mix in a $3-4 \mathrm{~km}$ deep boundary layer over Africa as a result of convergence, before overriding moister and cooler air and being advected westward over the Atlantic Ocean (Chatfield et al. 1998). In another study, it was shown that BB plumes from Central and Southern Africa are transported each year during the WAM season and carried westward by a jet located at $700 \mathrm{hPa}$ between 2 and $4 \mathrm{~km}$ altitude (Barbosa et al. 1999; Mari et al. 2008). In addition, Real et al. (2010) found ozone plumes in the mid- and upper troposphere over the Gulf of Guinea as a result of the long-range transport of BB from Central Africa. Using backward trajectories, Mari et al. (2008) demonstrated that the intrusion of BB into the upper troposphere of the Gulf of Guinea and the northern hemisphere was controlled by the active and break phases of the southern hemisphere's African Easterly Jet (AEJ) during the summer monsoon (JulyAugust 2006).

The number and size distributions of BB aerosols in southern West Africa (SWA) are dominated by the accumulation mode (Haslett et al. 2019). Likewise, according to a modeling study by Menut et al. (2018), BB from Central and Southern Africa has increased the level of air pollution in urban cities, such as Lagos and Abidjan (approximately $150 \mu \mathrm{g} \mathrm{m}^{-3}$ for $\mathrm{CO}, 10-20 \mu \mathrm{g} \mathrm{m}^{-3}$ for $\mathrm{O}_{3}$, and $5 \mu \mathrm{g} \mathrm{m}^{-3}$ for $\mathrm{PM}_{2.5}$ ). The contribution of $\mathrm{BB}$ in $\mathrm{PM}_{2.5}$ concentrations from Central Africa increased from $\sim 10 \%$ in May to $\sim 52 \%$ in July (Deroubaix et al. 2018). Haslett et al. (2019) found a significant aerosol mass concentration in the SWA boundary layer, both over the ocean and over the continental background, with similar chemical properties. They suggested that the upstream (Gulf of Guinea) aerosols originated from Central African BB, and demonstrated that these aerosols affected cloud optical properties but were less sensitive to precipitation. 
Although there have been studies, like the above, on the distribution and impact of $\mathrm{BB}$ in various regions the impact of $\mathrm{BB}$ aerosols from Central and Southern Africa on the meteorology and climate over SWA specifically has not yet been fully investigated.

Research during these past decades has shown that BB aerosols injected into the atmosphere have adverse effects on radiation and climate. Remote pollution from the long-range transport of $\mathrm{BB}$ appears to affect the levels of atmospheric aerosol pollution over SWA during the summer monsoon. It originates from Central and Southern Africa as a result of agricultural activities, land management, livestock grazing, and crop production. It is carried westward by the African Easterly Jet (AEJ) toward the tropical Atlantic Ocean, the Gulf of Guinea, and SWA, aloft at the mid-level troposphere $(2-4 \mathrm{~km})$. Recently, an intensive field campaign within the framework of Dynamics-Aerosol-Chemistry-Cloud Interactions in West Africa (DACCIWA) in SWA, observed large amounts of the BB as background concentration in the Planetary Boundary Layer (PBL), dominated by OC (Haslett et al. 2019).

In this chapter, then, the changes in atmospheric variables (precipitation, clouds, solar radiation) due to BB aerosols are examined. During a case study of 3 days (5-7 July 2016), two sets of simulations are performed: with and without BB. The differences make it possible to quantify the impacts of $\mathrm{BB}$ on the state of the atmosphere. The following research questions are addressed in this work:

- What is the relative contribution of BB aerosols to the atmospheric composition of the SWA region?

- What is the effect of BB on the climate of SWA?

- What are the practical behaviors and actions to be taken in order to reduce the level of pollution over SWA?

\section{Description of the Study Area and Methodology}

This section describes the study area, where the data was obtained (section "Study Area"), and the methodology used (section "Methods") to obtain the results.

\section{Study Area}

The study domains comprise an outer domain, that is, D1: West Africa, and a nested domain, that is, D2: southern West Africa (SWA), spreading from $3^{\circ} \mathrm{N}$ to $10^{\circ} \mathrm{N}$ and $9^{\circ} \mathrm{W}$ to $4^{\circ} \mathrm{E}$ (Fig. 1). The latitudinal extent of D1 $\left(18^{\circ} \mathrm{W}-26.6^{\circ} \mathrm{E} ; 20^{\circ} \mathrm{S}-24.6^{\circ} \mathrm{N}\right)$ covers the Sahel region, as well as the eastern Atlantic Ocean and Central Africa. The wide spatial coverage of D1 allows us to account for the long-range transport of aerosols, such as dust aerosol from the Sahel and the Sahara Desert and BB from Central Africa. The nested domain D2 $\left(9^{\circ} \mathrm{W}-4^{\circ} \mathrm{E} ; 3^{\circ}-10.8^{\circ} \mathrm{N}\right)$, located in SWA, is characterized by tropical forest in the South and grassland and savanna in the North. The climate is that of typical tropics zones governed by the North-South shift of the 
Fig. 1 Model domains D1 (outer domain) and D2 (nested domain) hacked in red. The horizontal resolution in case of D1 is $5 \mathrm{~km}$ and in case of $\mathrm{D} 2$ is $2.5 \mathrm{~km}$

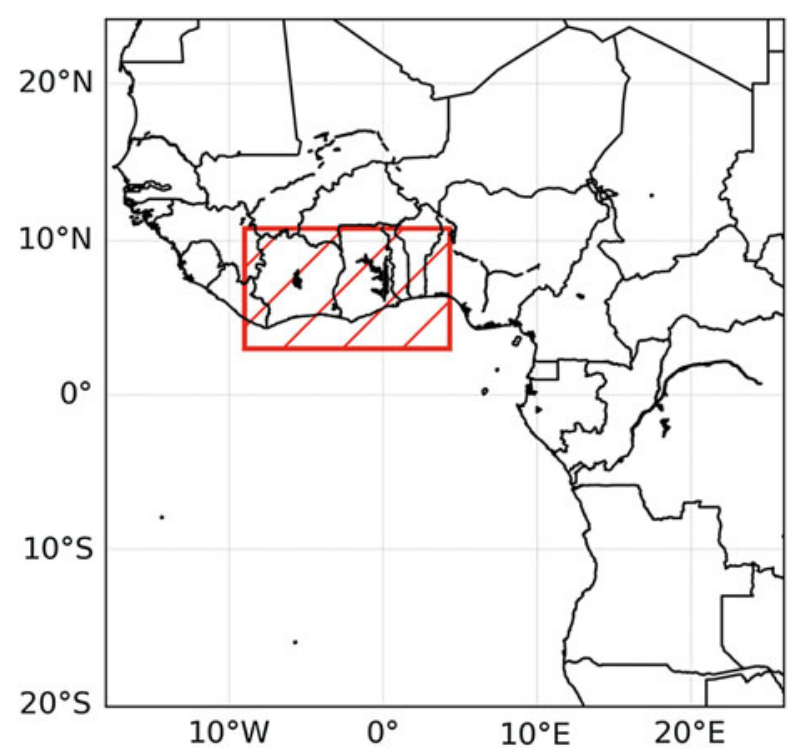

Intertropical Convergence Zone (ITCZ) or the Intertropical discontinuity (ITD) (over the land), which determines the rainy/dry seasons. During the period under investigation (July 2016), the WAM was prevalent in the study domain. The WAM is generated by the temperature gradient between the Atlantic Ocean, which is cool (monsoon), and the north (the Sahara Desert), which is warm.

\section{Methods}

This section describes the model setup (section "Model Setup") and the biomass burning experiment (section "Biomass Burning Experiment").

\section{Model Setup}

Simulations were performed with the regional scale model COSMO-ART (Vogel et al. 2009) at a spatial resolution of $5 \mathrm{~km}$ for D1 and nested to $2.5 \mathrm{~km}$ for D2 with 50 and 80 levels up to $30 \mathrm{~km}$ altitude above ground level (AGL), respectively. Simulations were run for 9 days over D1 (29 June-7 July 2016), and 3 days (5-7 July 2016) were analyzed over D2 as a case study for detailed investigation. COSMOART allows for the treatment of the aerosol dynamics, atmospheric chemistry, feedback with radiation, and cloud microphysics (Athanasopoulou et al. 2013; Bangert et al. 2012; Knote et al. 2010; Vogel et al. 2009). A gas flaring emission parameterization of the area of interest in SWA has been developed by Deetz and Vogel (2017), using a combination of remote sensing observations and physically based combustion equations to better reproduce the atmospheric chemistry of the 
area of interest. The implementation of a $1 \mathrm{D}$-plume rise model of $\mathrm{BB}$ aerosols and gases into COSMO-ART was realized by Walter et al. (2016), which calculates online the injection height (top and bottom limit) of the BB plume. For this study, several emission datasets from different sources have been used. The BB emissions data were obtained from the Global Fire Assimilation System (GFAS) version 1.2 (Kaiser et al. 2012). It is a satellite retrieved dataset of daily fire radiative power (FRP) measurements from the Moderate Resolution Imaging Spectroradiometer (MODIS) Terra and Aqua. Anthropogenic emissions were provided by the Emission Database for Global Atmospheric Research Hemispheric Transport of Air Pollution version 2 (EDGAR HTAP_v2) dataset (Edgar 2010) for 2010 with a $0.1^{\circ}$ grid mesh size. In addition, the new gas flaring emission from Deetz and Vogel (2017) was used for this study. Biogenic emissions, sea salt, and mineral dust are calculated online within the model, and mean dimethyl sulfide (DMS) monthly fluxes are prescribed after Lana et al. (2011). The initial and boundary conditions for the meteorology were provided from the global Icosahedral Nonhydrostatic (ICON) model of the German Weather Service (Zängl et al. 2015). The boundary data for gaseous and particulate compounds were derived from the Model for Ozone and Related Chemical Tracers (MOZART) (Emmons et al. 2010). The simulation setup used was similar to the one described in Deetz et al. (2018).

\section{Biomass Burning Experiment}

In order to assess the effects of BB over SWA, we carried out two sets of simulations: one with BB emissions (hereafter called Fire) and another one ignoring BB emissions (hereafter called No Fire) for the period under investigation. The experiment with BB includes real-time MODIS observations of fire emissions. Figure 2 presents surface $\mathrm{CO}$ emissions for the two case scenarios under investigation.
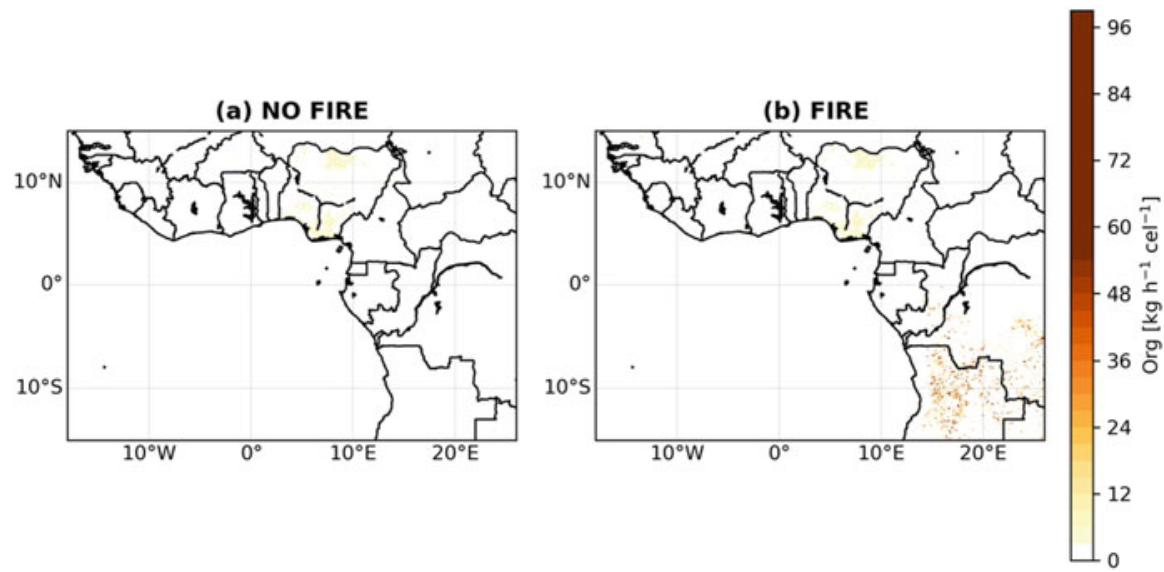

Fig. 2 Biomass burning July fire emissions for the No fire (a, 2016) and Fire (b, 2016) at the surface 
Due to its long lifetime and its reactivity, $\mathrm{CO}$ is used as a surrogate for $\mathrm{BB}$ detection. Moderate $\mathrm{CO}$ emissions are observed in SWA mostly over the city plumes (Abidjan, Accra, Cotonou, and Lagos) due to local anthropogenic emissions. Moderate CO emissions are also observed in the Niger Delta (in southwestern Nigeria), probably as a result of gas flaring activities, as well as in northern Nigeria. The peak of the $\mathrm{CO}$ emission is observed in Central and Southern Africa, where the BB is taking place.

\section{Results and Discussion}

This section presents the results obtained with regard to BB, by focusing on the impact on meteorology of the study area (section "Impact on Meteorology"), the impact on the atmospheric composition (section "Impact on the Atmospheric Composition"), and the adaptation and mitigation strategies proposed (section "Adaptation and Mitigation Strategies") as being helpful in reducing the impact of BB in the SWA region.

\section{Impact on Meteorology}

Our period of investigation is July 2016, which was characterized as the post-onset rainy season in SWA (Knippertz et al. 2017), thus favoring an undisturbed monsoon condition. During this period, long-range transport of BB is advected across the Eastern Atlantic Ocean and the Gulf of Guinea by a jet at around $700 \mathrm{hPa}$. In order to obtain quantitative results, a domain average over $\mathrm{D} 2\left(9^{\circ} \mathrm{W}-4^{\circ} \mathrm{E} ; 3^{\circ}-10.8^{\circ} \mathrm{N}\right)$, and the difference and relative change between the Fire and No Fire cases were analyzed. The effects of BB on the meteorological field in general (precipitation, temperature, and cloud droplets number) and on surface shortwave (SW) radiation were examined. Table 1 presents the mean effects over the SWA domain according to the variables for Fire and No Fire.

The results revealed a decrease in SW radiation at the surface and top of atmosphere (TOA) by $6.5 \mathrm{~W} \mathrm{~m}^{-2}$ and $5 \mathrm{~W} \mathrm{~m}^{-2}$, respectively, a slight decrease in precipitation, and an increase in the Cloud Droplets Number Concentration (CDNC)

Table 1 Mean values of meteorological fields for the Fire and No Fire scenarios, the difference (F-NF) and the change in percentage averaged over the nested domain $\mathrm{D} 2\left(9^{\circ} \mathrm{W}-4^{\circ} \mathrm{E} ; 3^{\circ}-10.8^{\circ} \mathrm{N}\right)$

\begin{tabular}{|c|c|c|c|c|}
\hline Field & Fire $(\mathrm{F})$ & No Fire (NF) & Difference & $\begin{array}{l}\text { \% change } \\
(\mathrm{F}-\mathrm{NF}) \\
* 100 / \mathrm{F})\end{array}$ \\
\hline Precipitation $\left(\mathrm{mm} \mathrm{day}^{-1}\right)$ & 4.15 & 4.26 & $-0.11 \pm 0.008$ & -2.7 \\
\hline SW down surface $\left(\mathrm{W} \mathrm{m}^{-2}\right)$ & 83.43 & 89.95 & $-6.51 \pm 0.0$ & -7.8 \\
\hline $\begin{array}{l}\text { Cloud droplet number (CDNC) } \\
\text { concentration }\left(\mathrm{cm}^{-3}\right)\end{array}$ & 94,767 & 85,542 & $10,225 \pm 853$ & 10.78 \\
\hline TOA net downward SW $\left(\mathrm{W} \mathrm{m}^{-2}\right)$ & 184.61 & 190.28 & $-5 \pm 0.0$ & -3.07 \\
\hline
\end{tabular}


over SWA. The decrease of surface SW radiation was expected, as aerosols directly reflect or scatter radiation, thus leading to a cooling effect, which in turn reduces the atmospheric stability and, thus, the surface fluxes called semi-direct effects. This result agrees with the findings of Thornhill et al. (2018).

The increase in the CDNC from our model results verifies the Twomey effect (Twomey 1977), which states that an increase in the amount of aerosols leads to a reduction in the cloud droplets size distribution that is associated with an increase in the number concentration.

Our finding corroborates with that of Haslett et al. (2019) which demonstrated that BB aerosols reduce droplet size and increase their number concentration over SWA but less sensitive to precipitation. As a result, more aerosols are competing for water uptake, leading to a reduction in precipitation (known as the Albrecht effect). This result is in agreement with the findings of Thornhill et al. (2018) regarding the impact of $\mathrm{BB}$ on precipitation. According to the latter an increase in the number of cloud droplets and a decrease in their size would lead to a decrease in precipitation in the absence of strong convection; however, the decrease here is less compared to their findings.

\section{Impact on the Atmospheric Composition}

In addition to investigating the impact of BB on the local climatology of SWA, this study also examined the relative contribution of $\mathrm{BB}$ to the atmospheric composition of SWA. The spatial distribution of the surface $\mathrm{CO}$ mixing ratio $(\mathrm{ppm})$ is presented in Fig. 3, over both domains, D1 and D2.

The two upper panels $(\mathrm{a}, \mathrm{b})$ depict the contribution of $\mathrm{BB}$ in $\mathrm{CO}$ concentration; it is marked by high values over Central and Southern Africa where BB occurred (Fig. 3b). Low values of traces of $\mathrm{CO}$ concentration can be observed over the Atlantic Ocean. The signature of anthropogenic activities is shown by moderate $\mathrm{CO}$ values $(0.6 \mathrm{ppm})$ over Lagos and the Niger Delta in southern Nigeria. The simulated CO concentration over D2 in the lower two panels (c, d) clearly illustrate the plumes above the cities (Abidjan, Accra, Cotonou, Lomé, and Lagos); they show moderate values, expect for Lagos, which exhibits the highest $\mathrm{CO}$ concentration from both experiments (No Fire and Fire). Kumasi (Ghana), a metropolitan area, also shows a moderate $\mathrm{CO}$ concentration as a result of anthropogenic activities. It is worth noting that Kumasi, a city with the third highest population in SWA (3.065 million inhabitants), is one of the most populated area in Ghana (UNO 2018). The $\mathrm{CO}$ concentration in SWA cities along the coast is the result of urban pollution. Figure $3 \mathrm{~d}$ highlights the contribution of $\mathrm{BB}$ plumes to the region by showing moderate $\mathrm{CO}$ concentrations $(0.3 \mathrm{ppm})$ over the Gulf of Guinea. This is the result of the intrusion of BB air masses into the atmosphere. Indeed, Mari et al. (2008) have shown that $\mathrm{BB}$ aerosols are carried aloft and advected westward by a jet at roughly $700 \mathrm{hPa}$. Layers of BB across SWA, the Gulf of Guinea, and the tropical eastern Atlantic are present during this period of the year (i.e., July 2016) (Chatfield et al. 1998; Mari et al. 2008). The presence of CO from BB in the marine boundary layer mainly arises from subsidence of the aerosols being carried aloft, due to the high 


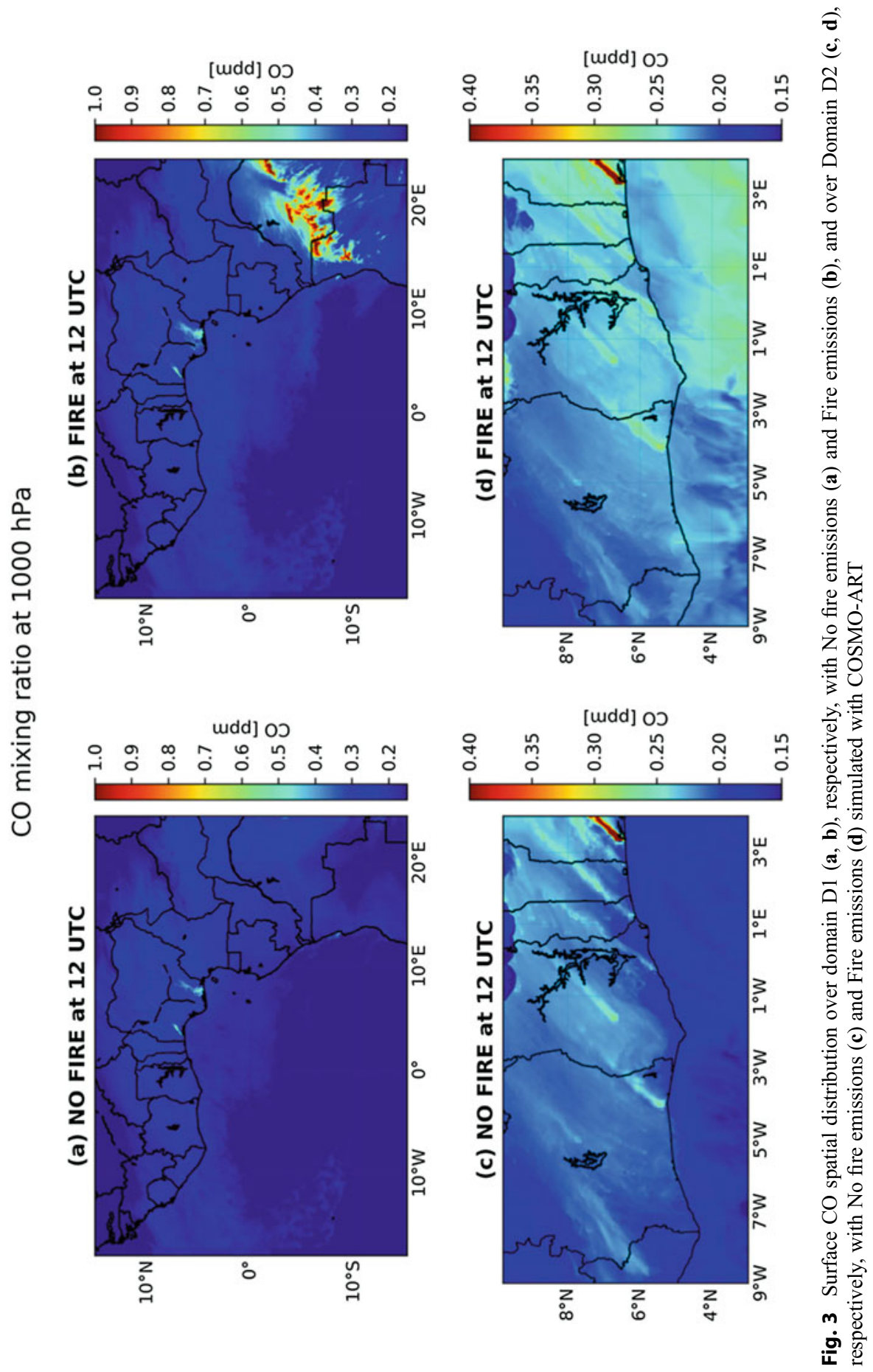


pressure area to the west of the African continent (Adebiyi and Zuidema 2016; Flamant et al. 2018). A recent study by Dajuma et al. (2020, in press) demonstrated that convective cumulus clouds located over the Gulf of Guinea play a role in the downward mixing of aerosols located at the mid-level troposphere into the PBL. The southerly monsoon flow in the PBL below $700 \mathrm{hPa}$ carries both BB aerosols and urban gases and aerosols northward (Deroubaix et al. 2019; Knippertz et al. 2017).

The relative contribution of $\mathrm{BB}$ to the $\mathrm{PM}_{25}$ over urban cities was also examined in our study. Time series of surface concentrations of $\mathrm{PM}_{25}$ examined for the period simulated over four SWA cities. The results, as illustrated in Fig. 4, are presented for Abidjan, Accra, Cotonou, and Lagos, for simulations with No Fire, Fire, and the difference between the two scenarios (Fire - No Fire).

The diurnal cycle shows a peak of $\mathrm{PM}_{25}$ concentration in the early morning around 6 UTC, which begins to decrease after sunrise. The increase of the PBL height results in a mixing of aerosols, highlighted by a decrease with a minimum value around 15 UTC (Fig. 4a). After sunset, the aerosols start to accumulate again. The impact of BB aerosols appears after only 1 day of simulation (from 6 July 2016). For all four cities, the impact of BB has the same order of magnitude, underscoring the wide extent of long-range BB over SWA. The maximum contribution found was $9.75 \mu \mathrm{g} \mathrm{m}^{-3}, 12.45 \mu \mathrm{g} \mathrm{m}^{-3}, 10.7 \mu \mathrm{g} \mathrm{m}^{-3}$, and $8 \mu \mathrm{g} \mathrm{m}^{-3}$, respectively, in Accra, Abidjan, Cotonou, and Lagos. Menut et al. (2018) quantified the contribution of BB to the $\mathrm{PM}_{10}$ concentration to be about $5 \mu \mathrm{g} \mathrm{m}^{-3}$ in two SWA cities (Lagos and Abidjan). Although $\mathrm{PM}_{25}$ and $\mathrm{PM}_{10}$ are composed of the same type of aerosols, only at different sizes, it is expected that the contribution to $\mathrm{PM}_{25}$ will be higher (double) than that of $\mathrm{PM}_{10}$. This confirms that $\mathrm{BB}$ aerosols are dominated by the submicron mode, as observed by Haslett et al. (2019).

Our model allowed us to quantify the contributions from each type of aerosol and gases as well. Table 2 thus summarizes the contribution of $\mathrm{BB}$ to $\mathrm{OC}, \mathrm{BC}, \mathrm{CO}, \mathrm{NO}_{\mathrm{x}}$, OZONE, and the Aerosol Optical Depth (AOD).

The relation between AOD and aerosol increase is clearly shown. A 36\% increase of AOD from $\mathrm{BB}$ contribution is simulated by COSMO-ART highlighting the positive relationship between $\mathrm{BB}$ aerosols and $\mathrm{AOD}$, in agreement with the findings of (Reddington et al. 2015). Thus, according to our model results, BB significant effect on AOD.

From the analysis of Table 2, it can be seen that BB plumes increased the atmospheric composition of both gases and aerosols concentrations in SWA. The major contribution of aerosols is from OC, representing a $70 \%$ increase due to $\mathrm{BB}$, followed by BC, which accounted for $24.5 \%$. These results agreed with the observations made during the DACCIWA campaign, which showed that $80 \%$ of the aerosol mass concentration in the monsoon layer (below $1.9 \mathrm{~km}$ ) in SWA was that originated from Central and Southern African BB (Haslett et al. 2019). Also, Menut et al. (2018), through modeling with the Weather Research and Forecasting model coupled with Chemistry (WRF-Chem), found that the contribution of $\mathrm{PM}_{10}$ from $\mathrm{BB}$ in Central Africa was mainly composed of primary organic and particulate matter (PM).

Among the gases, the ozone contribution from $\mathrm{BB}$ was $16 \%$, followed by $\mathrm{CO}$ at $11 \%$, then $\mathrm{NO}_{\mathrm{x}}$ at roughly $8 \%$. Real et al. (2010) found that the BB plume over 


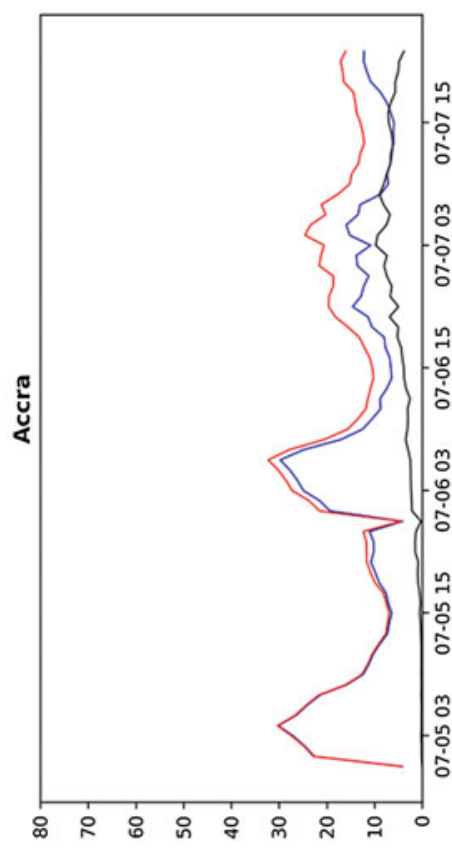

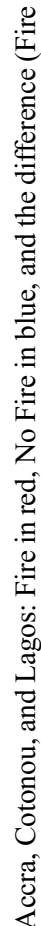
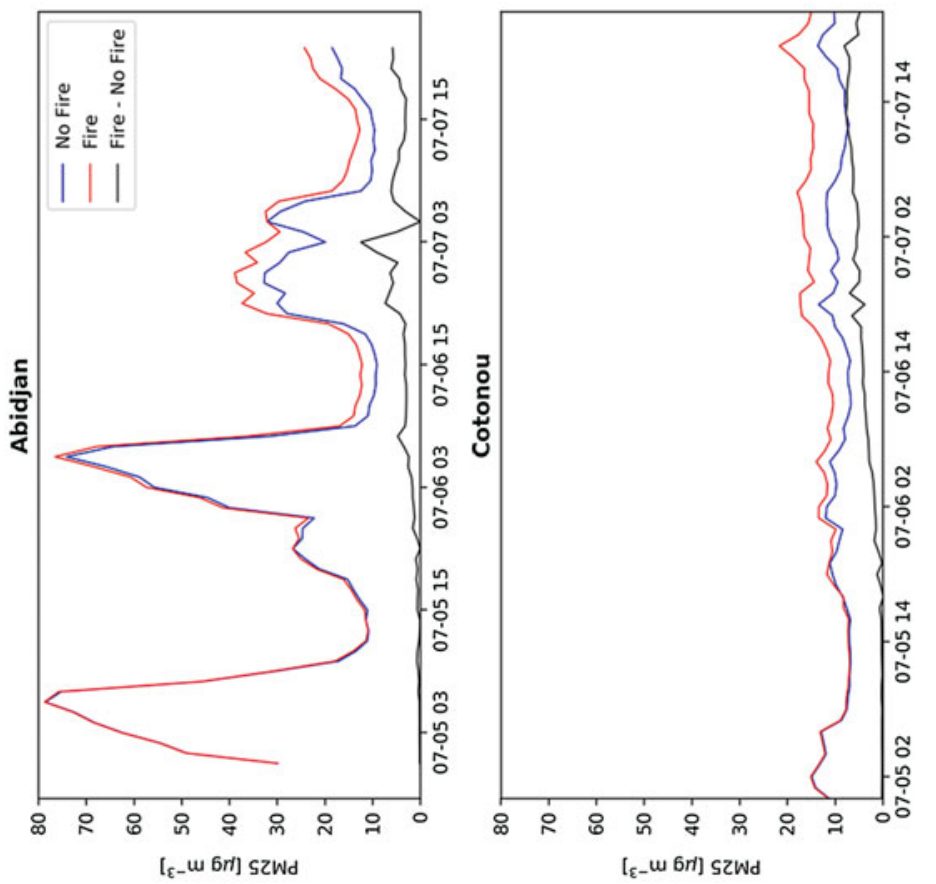

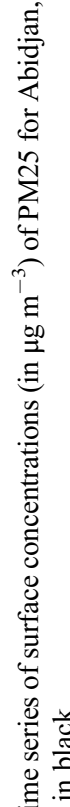

湻

현? 
Table 2 Mean values of aerosols mass concentration and gas mixing ratio for the Fire and No Fire scenarios, the difference (F-NF), and the change in percentage averaged over the nested domain D2 $\left(9^{\circ} \mathrm{W}-4^{\circ} \mathrm{E} ; 3^{\circ}-10.8^{\circ} \mathrm{N}\right)$

\begin{tabular}{l|l|l|l|l}
\hline Concentration & Fire $(\mathrm{F})$ & No Fire $(\mathrm{NF})$ & Difference & $\begin{array}{l}\text { \% change } \\
(\mathrm{F}-\mathrm{NF}) * 100 / \mathrm{F}\end{array}$ \\
\hline $\mathrm{AOD}$ & 0.39 & 0.25 & $0.14 \pm 0.01$ & 36 \\
\hline $\mathrm{CO}(\mathrm{ppb})$ & 225 & 199 & $26 \pm 1$ & 11.5 \\
\hline OZONE $(\mathrm{ppb})$ & 39 & 33 & $6 \pm 0.3$ & 16 \\
\hline $\mathrm{NO}_{\mathrm{x}}(\mathrm{ppb})$ & 26.18 & 24.1 & $2.07 \pm 0.3$ & 7.98 \\
\hline SOOT $\left(\mu \mathrm{g} \mathrm{m}^{-3}\right)$ & 0.196 & 0.148 & $0.05 \pm 0.004$ & 24.5 \\
\hline OC $\left(\mu \mathrm{g} \mathrm{m}^{-3}\right)$ & 3.15 & 0.93 & $2.21 \pm 0.14$ & 70.32
\end{tabular}

Central Africa was a source of ozone in the mid-level and upper troposphere. Moreover, Mari et al. (2008), tracing BB aerosol from the southern hemisphere during the summer monsoon, found ozone production to vary, depending on the meteorological conditions associated with the active and break phases of the southern hemisphere jet.

The presence of $\mathrm{BB}$ in the $\mathrm{PBL}$ increases the level of air of pollution which increases pollution-related diseases (Lelieveld et al. 2015). Intensive measurements during the DACCIWA campaign in both the dry and wet seasons confirmed that carbonaceous aerosols ( $\mathrm{OC}$ and $\mathrm{BC}$ ) were major contributions to particle fractions in Abidjan and Cotonou (Adon et al. 2020). The high content of organic aerosol from $\mathrm{BB}$ also has adverse effects on population health throughout the region. For instance, a study by Mauderly and Chow (2008) indicated that organic fractions of ambient PM have adverse respiratory and cardiovascular health outcomes.

\section{Adaptation and Mitigation Strategies}

The detrimental effects of air pollution are recognized worldwide, particularly in West Africa (Knippertz et al. 2015), as this region appears to suffer most from climate change as a result of anthropogenic activities. Increasing levels of local pollution and pollution from remote aerosol sources, such as BB from Central Africa and mineral dust from the Sahel and the Sahara, are increasing the aerosol burden over the SWA region. Consequently, poor air quality exposes the population to serious health risks, particularly people living in the coastal cities. Since urbanization is increasing worldwide, there is a need to implement effective management plans and policies to improve adaptive capacity and mitigate the effects of anthropogenic induced air pollution in SWA. An air quality monitoring network should be established in SWA in order to regulate air quality throughout the region over the long term, as suggested by the DACCIWA policy brief (Evans et al. 2019). This will also help to spread awareness among the population of areas of high pollution thus reducing the prevalence of respiratory illnesses, such as asthma. Local populations should be encouraged to shift from using wood and charcoal for cooking to instead using electricity or gas in order to reduce local emissions. For instance, Adon et al. 
(2020), focusing on local sources domestic fires in Abidjan, showed that $75 \%$ of the total PM are carbonaceous aerosols.

Regionally, negotiations are necessary between Central Africa and West Africa in order to reduce both regions' BB emissions, as recommended by the DACCIWA policy brief (Evans et al. 2019). It is furthermore important to develop air pollution policies in SWA. Weather forecasting is an essential tool to mitigate air pollutionrelated effects. There is a need to improve weather forecasting in SWA, not only in the meteorological field but also to account for aerosols, as these interact with the climate.

Another recommendation is to promote the use of renewable energy, such as solar, for use in industries to reduce the consumption of fossils fuels, which are also exacerbating air pollution. With regard to transportation, the traffic fleet in the SWA region is dominated by old cars (Doumbia et al. 2018). Regulations should be implemented to ban the use of old cars and to improve the public transportation systems in SWA, as both are major sources of pollutants.

By means of climate education and the promotion of green lifestyles the local community could be educated, assisted, and encouraged to participate in the mitigation of climate change. And lastly, it is also recommended that increasing observational networks over SWA and improving modeling tools (e.g., cluster) and human capacity would be effective and efficient ways of tackling issues related to climate change.

\section{Conclusions}

It has been found in our study that remote pollution from the long-range transport of BB appears to affect the atmospheric aerosol pollution over SWA during summer monsoon. BB plumes originate from Central and Southern Africa as a result of agricultural activities, land management, livestock grazing, and crop production. They are carried westward by a jet toward the tropical eastern Atlantic Ocean, the Gulf of Guinea and SWA in the mid-level troposphere. BB aerosols were shown to increase the concentration of PM over four coastal cities in SWA in the same range of magnitude. Increase in $\mathrm{PM}_{25}$ of $12.45 \mu \mathrm{g} \mathrm{m}^{-3}, 9,75 \mu \mathrm{g} \mathrm{m}^{-3}, 8 \mu \mathrm{g} \mathrm{m}^{-3}$, and $10.7 \mu \mathrm{g} \mathrm{m}^{-3}$ was simulated, respectively, for Abidjan, Accra, Lagos, and Cotonou. Observational studies have shown that $\mathrm{PM}_{25}$ aerosols measured in the ADF, for instance, have exceeded the limits set by the World Health Organisation (WHO) limit (Djossou et al. 2018).

Relative contributions of $\mathrm{BB}$ to gaseous pollutants such as $\mathrm{NO}_{\mathrm{x}}, \mathrm{CO}$, and Ozone are, respectively, $7.98 \%, 11.5 \%$, and $16 \%$. As far as aerosols are concerned, OC is the dominant contributor to the atmospheric composition from $\mathrm{BB}$ with a $70 \%$ increase, followed by BC with a $24 \%$ increase. The AOD change as a result of BB aerosol is estimated at $36 \%$.

Regarding the effect on climate, it was found that SW radiation decreased by $6.5 \mathrm{~W} \mathrm{~m}^{-2}$ at the surface and $5 \mathrm{~W} \mathrm{~m}^{-2}$ at the TOA. The mean domain average of CDNC increased by $11 \%$ from the No Fire to the Fire case scenario, followed by a 
slight decrease in precipitation. It is worth noting that this experiment was conducted only over a few days. However, the results do emphasize that there is a need to explore further and obtain more robust results by performing long-term simulations. Based on the results obtained with our model, it is obvious that BB aerosols from the southern hemisphere of Africa are interacting with the WAM dynamics; these interactions need to be investigated in future studies.

In addition, there is a need to implement an air pollution monitoring system to tackle health problems related to pollution and increase the adaptive capacity of West Africa to climate change by limiting local pollution. Moreover, there is a need to implement transboundary agreements in policies making, for example, by collaborating with countries in Central Africa to reduce their emissions from vegetation fires, as suggested by the DACCIWA policy brief (Evans et al. 2019).

\section{References}

Adebiyi AA, Zuidema P (2016) The role of the southern African easterly jet in modifying the Southeast Atlantic aerosol and cloud environments. Q J R Meteorol Soc. https://doi.org/ 10.1002/qj.2765

Adon AJ, Liousse C, Doumbia ET, Baeza-Squiban A et al (2020) Physico-chemical characterization of urban aerosols from specific combustion sources in West Africa at Abidjan in Côte d'Ivoire and Cotonou in Benin in the frame of the DACCIWA program. Atmos Chem Phys 20: 5327-5354. https://doi.org/10.5194/acp-20-5327-2020

Athanasopoulou E, Vogel H, Vogel B et al (2013) Modeling the meteorological and chemical effects of secondary organic aerosols during an EUCAARI campaign. Atmos Chem Phys 13:625-645. https://doi.org/10.5194/acp-13-625-2013

Bangert M, Nenes A, Vogel B et al (2012) Saharan dust event impacts on cloud formation and radiation over Western Europe. Atmos Chem Phys 12:4045-4063. https://doi.org/10.5194/acp12-4045-2012

Barbosa PM, Stroppiana D, Grégoire JM, Pereira JMC (1999) An assessment of vegetation fire in Africa (1981-1991): burned areas, burned biomass, and atmospheric emissions. Global Biogeochem Cycles. https://doi.org/10.1029/1999GB900042

Bowman DMJS, Balch J, Artaxo P et al (2011) The human dimension of fire regimes on earth. J Biogeogr 38:2223-2236. https://doi.org/10.1111/j.1365-2699.2011.02595.x

Chatfield RB, Vastano JA, Li L et al (1998) The Great African Plume from biomass burning: generalizations from a three-dimensional study of TRACE A carbon monoxide. J Geophys Res Atmos 103:28059-28077. https://doi.org/10.1029/97JD03363

Dajuma A, Ogunjobi KO, Vogel H et al (2020) Downward cloud venting of the central African biomass burning plume during the West Africa summer monsoon. Atmos Chem Phys 20:53735390. https://doi.org/10.5194/acp-5373-2020

Deetz K, Vogel B (2017) Development of a new gas-flaring emission dataset for southern West Africa. Geosci Model Dev 10:1607-1620. https://doi.org/10.5194/gmd-10-1607-2017

Deetz K, Vogel H, Knippertz P et al (2018) Numerical simulations of aerosol radiative effects and their impact on clouds and atmospheric dynamics over southern West Africa. Atmos Chem Phys 18:9767-9788. https://doi.org/10.5194/acp-18-9767-2018

Deroubaix A, Flamant C, Menut L et al (2018) Interactions of atmospheric gases and aerosols with the monsoon dynamics over the Sudano-Guinean region during AMMA. Atmos Chem Phys 18:445-465. https://doi.org/10.5194/acp-18-445-2018

Deroubaix A, Menut L, Flamant C et al (2019) Diurnal cycle of coastal anthropogenic pollutant transport over southern West Africa during the DACCIWA campaign. Atmos Chem Phys 19:473-497. https://doi.org/10.5194/acp-19-473-2019 
Djossou J, Léon JF, Barthélemy AA et al (2018) Mass concentration, optical depth and carbon composition of particulate matter in the major southern West African cities of Cotonou (Benin) and Abidjan (Côte d'Ivoire). Atmos Chem Phys 18:6275-6291. https://doi.org/10.5194/acp-186275-2018

Doumbia M, Toure NE, Silue S et al (2018) Emissions from the road traffic of West African cities: assessment of vehicle fleet and fuel consumption. Energies 11:1-16. https://doi.org/10.3390/ en 11092300

Edgar (2010) EDGAR - Emission Database for Global Atmospheric Research. Glob Emiss EDGAR v42 (November 2011). https://doi.org/10.2904/EDGARv4.2

Emmons LK, Walters S, Hess PG et al (2010) Description and evaluation of the Model for Ozone and Related chemical Tracers, version 4 (MOZART-4). Geosci Model Dev 3:43-67. https://doi. org/10.5194/gmd-3-43-2010

Evans MJ, Knippertz P, Aristide A, Allan RP (2019) Policy-relevant findings of the DACCIWA. https://doi.org/10.5281/zenodo. 1476843

Flamant C, Deroubaix A, Chazette P et al (2018) Aerosol distribution in the northern Gulf of Guinea: local anthropogenic sources, long-range transport, and the role of coastal shallow circulations. Atmos Chem Phys 18:12363-12389. https://doi.org/10.5194/acp-18-12363-2018

Hao WM, Liu MH (1994) Spatial and temporal distribution of tropical biomass burning. Global Biogeochem Cycles. https://doi.org/10.1029/94GB02086

Haslett SL, Taylor JW, Evans M et al (2019) Remote biomass burning dominates southern West African air pollution during the monsoon. Atmos Chem Phys 19:15217-15234. https://doi.org/ 10.5194/acp-19-15217-2019

Huang J, Adams A, Wang C, Zhang C (2013) Black Carbon and West African Monsoon precipitation: observations and simulations. Ann Geophys 27:4171-4181

Huang X, Ding A, Liu L et al (2016) Effects of aerosol-radiation interaction on precipitation during biomass-burning season in East China. Atmos Chem Phys 16:10063-10082. https://doi.org/ 10.5194/acp-16-10063-2016

Jiang Y, Lu Z, Liu X et al (2016) Impacts of global open-fire aerosols on direct radiative, cloud and surface-albedo effects simulated with CAM5. Atmos Chem Phys 16:14805-14824. https://doi. org/10.5194/acp-16-14805-2016

Kaiser JW, Heil A, Andreae MO et al (2012) Biomass burning emissions estimated with a global fire assimilation system basedon observed fire radiative power. Biogeosciences 9:527-554. https:// doi.org/10.5194/bg-9-527-2012

Knippertz P, Evans MJ, Field PR et al (2015) The possible role of local air pollution in climate change in West Africa. Nat Clim Chang 815-822. https://doi.org/10.1038/nclimate2727

Knippertz P, Fink AH, Deroubaix A et al (2017) A meteorological and chemical overview of the DACCIWA field campaign in West Africa in June-July 2016. Atmos Chem Phys 17:1089310918. https://doi.org/10.5194/acp-17-10893-2017

Knote C, Brunner D, Vogel H et al (2010) Online-coupled chemistry and aerosols: COSMO-ART modelperformance

Lana A., Bell T. G,. Simó R., et al (2011) An updated climatology of surface dimethlysulfide concentrations and emission fluxes in the global ocean. Global Biogeochem Cycles 25:1-17. https://doi.org/10.1029/2010GB003850

Lelieveld J, Fnais M, Evans JS et al (2015) The contribution of outdoor air pollution sources to premature mortality on a global scale. Nature 525:367-371. https://doi.org/10.1038/ nature 15371

Marenco A, Medale JC, Prieur S (1990) Study of tropospheric ozone in the tropical belt (Africa, America) from STRATOZ and TROPOZ campaign. Atmos Environ 24:2823-2834. https://doi. org/10.1016/0960-1686(90)90169-N

Mari CH, Cailley G, Corre L et al (2008) Tracing biomass burning plumes from the Southern Hemisphere during the AMMA 2006 wet season experiment. Atmos Chem Phys 8:3951-3961. https://doi.org/10.5194/acp-8-3951-2008

Mauderly JL, Chow JC (2008) Health effects of organic aerosols. Inhal Toxicol 20:257-288. https:// doi.org/10.1080/08958370701866008 
Mbow C, Nielsen TT, Rasmussen KC (2000) Savanna fires in East-Central Senegal: distribution patterns, resource management and perceptions. Hum Ecol 28(4):561-583

Menut L, Flamant C, Turquety S et al (2018) Impact of biomass burning on pollutant surface concentrations in megacities of the Gulf of Guinea. Atmos Chem Phys 18:2687-2707. https:// doi.org/10.5194/acp-18-2687-2018

N'Datchoh ET, Konaré A, Diedhiou A et al (2015) Effects of climate variability on savannah fire regimes in West Africa. Earth Syst Dynam 6:161-174. https://doi.org/10.5194/esd-6-161-2015

Pani SK, Wang SH, Lin NH et al (2016) Radiative effect of springtime biomass-burning aerosols over northern Indochina during 7-SEAS/BASELInE 2013 campaign. Aerosol Air Qual Res 16:2802-2817. https://doi.org/10.4209/aaqr.2016.03.0130

Real E, Orlandi E, Law KS et al (2010) Cross-hemispheric transport of central African biomass burning pollutants: implications for downwind ozone production. Atmos Chem Phys 10:30273046. https://doi.org/10.5194/acp-10-3027-2010

Reddington CL, Butt EW, Ridley DA et al (2015) Air quality and human health improvements from reductions in deforestation-related fire in Brazil. Nat Geosci 8:768-771. https://doi.org/10.1038/ ngeo 2535

Stowe LL, Jacobowitz H, Ohring G et al (2002) The advanced very high resolution radiometer (AVHRR) pathfinder atmosphere (PATMOS) climate dataset: initial analyses and evaluations. J Clim 15:1243-1260. https://doi.org/10.1175/1520-0442(2002)015<1243:TAVHRR > 2.0. $\mathrm{CO} ; 2$

Swap RJ, Annegarn HJ, Suttles JT et al (2002) The southern African regional science initiative (SAFARI 2000): overview of the dry season field campaign. S Afr J Sci 98:125-130

Thornhill GD, Ryder CL, Highwood EJ et al (2018) The effect of south American biomass burning aerosol emissions on the regional climate. Atmos Chem Phys 18:5321-5342. https://doi.org/ 10.5194/acp-18-5321-2018

Twomey S (1977) The influence of pollution on the shortwave albedo of clouds. J Atmos Sci 34:1149-1152. https://doi.org/10.1175/1520-0469(1977)034<1149:TIOPOT > 2.0.CO;2

UNO (2018) The world's cities in 2018. https://doi.org/10.18356/c93f4dc6-en

Vogel B, Vogel H, Bäumer D et al (2009) The comprehensive model system COSMO-ART radiative impact of aerosol on the state of the atmosphere on the regional scale. Atmos Chem Phys 9:8661-8680. https://doi.org/10.5194/acp-9-8661-2009

Walter C, Freitas SR, Kottmeier C et al (2016) The importance of plume rise on the concentrations and atmospheric impacts of biomass burning aerosol. Atmos Chem Phys 16:9201-9219. https:// doi.org/10.5194/acp-16-9201-2016

Zängl G, Reinert D, Rípodas P, Baldauf M (2015) The ICON (ICOsahedral non-hydrostatic) modelling framework of DWD and MPI-M: description of the non-hydrostatic dynamical core. Q J R Meteorol Soc 141:563-579. https://doi.org/10.1002/qj.2378

Open Access This chapter is licensed under the terms of the Creative Commons Attribution 4.0 International License (http://creativecommons.org/licenses/by/4.0/), which permits use, sharing, adaptation, distribution and reproduction in any medium or format, as long as you give appropriate credit to the original author(s) and the source, provide a link to the Creative Commons license and indicate if changes were made.

The images or other third party material in this chapter are included in the chapter's Creative Commons license, unless indicated otherwise in a credit line to the material. If material is not included in the chapter's Creative Commons license and your intended use is not permitted by statutory regulation or exceeds the permitted use, you will need to obtain permission directly from the copyright holder.

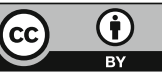

